\title{
Presynaptic kainate receptors modulating glutamatergic transmission in the rat hippocampus are inhibited by arachidonic acid
}

\author{
Rodrigo A. Cunha ${ }^{\mathrm{a}, *}$, J.A. Ribeiro ${ }^{\mathrm{b}}$, João O. Malva ${ }^{\mathrm{a}}$ \\ ${ }^{a}$ Center for Neuroscience of Coimbra, Institute of Biochemistry, Faculty of Medicine, University of Coimbra, 3004-504 Coimbra, Portugal \\ ${ }^{\mathrm{b}}$ Laboratory of Neurosciences, Faculty of Medicine, University of Lisbon, Lisbon, Portugal
}

Received 6 May 2003; accepted 4 June 2003

\begin{abstract}
Kainate receptors are ionotropic glutamate receptors located postsynaptically, mediating frequency-dependent transmission, and presynaptically, modulating transmitter release. In contrast to the excitatory postsynaptic kainate receptors, presynaptic kainate receptor can also be inhibitory and their effects may involve a metabotropic action. Arachidonic acid (AA) modulates most ionotropic receptors, in particular postsynaptic kainate receptor-mediated currents. To further explore differences between pre- and postsynaptic kainate receptors, we tested if presynaptic kainate receptors are affected by AA. Kainate $(0.3-3 \mu \mathrm{M})$ and the kainate receptor agonist, domoate (60-300 nM), inhibited by $19-54 \%$ the field excitatory postsynaptic potential (fEPSP) slope in rat CA1 hippocampus, and increased by $12-32 \%$ paired-pulse facilitation (PPF). AA $(10 \mu \mathrm{M})$ attenuated by $37-72 \%$ and by $62-66 \%$ the domoate $(60-300 \mathrm{nM})$-induced fEPSP inhibition and paired-pulse facilitation increase, respectively. This inhibition by AA was unaffected by cyclo- and lipo-oxygenase inhibitors, indomethacin (20 $\mu \mathrm{M})$ and nordihydroguaiaretic acid (NDGA, $50 \mu \mathrm{M})$ or by the free radical scavenger, $N$-acetyl-L-cysteine $(0.5 \mathrm{mM})$. The $\mathrm{K}^{+}(20 \mathrm{mM})$-evoked release of $\left[{ }^{3} \mathrm{H}\right]$ glutamate from superfused hippocampal synaptosomes was inhibited by $18-39 \%$ by domoate $(1-10 \mu \mathrm{M})$, an effect attenuated by $35-63 \%$ by AA $(10 \mu \mathrm{M})$. Finally, the $K_{\mathrm{D}}(40-55 \mathrm{nM})$ of the kainate receptor agonist $\left[{ }^{3} \mathrm{H}\right]-(2 S, 4 R)-4-$ methylglutamate $\left(\left[{ }^{3} \mathrm{H}\right] \mathrm{MGA}\right)$ $(0.3-120 \mathrm{nM})$ binding to hippocampal synaptosomal membranes was increased by $151-329 \%$ by AA (1-10 $\mu \mathrm{M})$. These results indicate that AA directly inhibits presynaptic kainate receptor controlling glutamate release in the CA1 area of the rat hippocampus.

(C) 2003 Elsevier Ltd. All rights reserved.
\end{abstract}

Keywords: Kainate; Arachidonic acid; Hippocampus; Synaptic transmission; Nerve terminals; Glutamate release; Binding

\section{Introduction}

Kainate receptors are a subtype of ionotropic glutamate receptors that are abundantly expressed in the hippocampus (for review see, Lerma et al., 2001). Kainate receptors mediate frequency-dependent transmission in mossy fiber/CA3 pyramidal cell synapses and in CA1 interneurons (reviewed in Kamiya, 2002). Kainate receptors also fulfil a neuromodulatory role in the hippocampus, mainly through a presynaptic action (reviewed in Malva et al., 2003). Interestingly in the hippocampal CA1 area, a robust activation of presynaptic kainate receptors leads to inhibition of glutamatergic transmission and glutamate release (e.g. Chittajallu et al., 1996; Kamiya and Ozawa, 1998) as well as GABAergic transmission and GABA release (e.g. Rodríguez-Moreno and Lerma, 1998; Cunha et al., 2000a). These presynaptic inhibitory effects are at odds with the expected depolar-

\footnotetext{
* Corresponding author. Tel.: +351-239-820190; fax: +351-239-822776.

E-mail address: racunha@clix.pt (R.A. Cunha).
}

izing effect of kainate receptor-gated ionotropic channels permeable to cations (reviewed in Lerma et al., 2001). Interestingly, it was found that the inhibition of GABA and glutamate release by activation of kainate receptors in the CA1 area of the hippocampus involves a metabotropic pathway since it is disrupted by interference with $\mathrm{Gi} / \mathrm{Go}$ protein (Rodríguez-Moreno and Lerma, 1998; Cunha et al., 2000a; Frerking et al., 2001). Surprisingly, the only pharmacological difference between these presynaptic kainate receptors triggering metabotropic responses and their postsynaptic counterparts ion channels is a different sensitivity to agonists in the case of GABAergic neurons (Rodríguez-Moreno et al., 2000).

It was reported that cis-unsaturated fatty acids, like the trans-cellular messenger arachidonic acid (AA; see Lynch et al., 1991), inhibit kainate receptor-mediated responses (Wilding et al., 1998). In this work (Wilding et al., 1998), it was reported that AA inhibits the currents triggered by kainate receptor activation but it is not known if AA also affects presynaptic kainate receptors. Indeed, in contrast to the AA modulation of ion channels, which normally results 
from a direct interaction of AA with voltage sensitive ion channels or receptor-operated ion channels (e.g. Kovalchuck et al., 1994; Meves, 1994; Miller et al., 1992; Wilding et al., 1998), the AA modulation of metabotropic receptors involves the activation of protein kinase $\mathrm{C}$ (e.g. Cunha and Ribeiro, 1999; Cunha et al., 2000b; Freeman et al., 1990). Thus, as a way to further elucidate the nature of presynaptic kainate receptors controlling hippocampal glutamatergic transmission, we now tested if presynaptic inhibitory responses mediated by kainate receptors in the hippocampus were also sensitive to AA.

\section{Methods}

\subsection{Chemicals and solutions}

Domoic acid, 5-nitro-6,7,8,9-tetrahydrobenzo(g)indole2,3-dione-3-oxime (NS-102) and 1-(4-aminophenyl)-4methyl-7,8-methylenedioxy-5H-2,3-benzodiazepine (GYKI 52466) were from Research Biochemicals International, kainate, bovine serum albumin (BSA, fatty acid free), $\mathrm{N}$-acetyl-L-cysteine, indomethacin, nordihydroguaiaretic acid (NDGA), linolenic acid, arachidic acid, ETYA $(5,8,11,14$-eicosatetraynoic acid) and arachidonic acid were from Sigma, $\left[{ }^{3} \mathrm{H}\right]-(2 S, 4 R)-4$-methylglutamate $\left(\left[{ }^{3} \mathrm{H}\right] \mathrm{MGA}\right)$ and 6-cyano-7-nitroquinoxaline-2,3-dione (CNQX) were from Tocris Cookson and $\left[{ }^{3} \mathrm{H}\right]$ glutamate (specific activity $45 \mathrm{Ci} / \mathrm{mmol}$ ) was from Amersham. Free fatty acids were made up into a $30 \mathrm{mM}$ stock solution in ethanol, aliquoted and stored under nitrogen atmosphere at $-20^{\circ} \mathrm{C}$. Indomethacin was made up into a $20 \mathrm{mM}$ stock in methanol and nordihydroguaiaretic acid was made up into a $20 \mathrm{mM}$ stock in ethanol. GYKI 52466 was made up in a $1 \mathrm{mg} / \mathrm{ml}$ solution in methanol and NS-102 was made up in a $5 \mathrm{mM}$ stock in dimethylsulfoxide. Aqueous dilutions of these stock solutions were made daily. The maximal concentrations of ethanol, methanol or dimethylsulfoxide used were devoid of effects on synaptic transmission and on $\left[{ }^{3} \mathrm{H}\right]$ glutamate release.

\subsection{Electrophysiological recordings of hippocampal synaptic transmission}

The handling and use of the animals was according with the EU guidelines for use of experimental animals (86/609/EEC), the rats being anesthetized under halothane atmosphere before being sacrificed by decapitation to minimize suffering. One $400 \mu \mathrm{m}$ hippocampal slice, obtained as previously described (Cunha et al., 2000b) from 6 to 8 weeks old male Wistar rats, was transferred to a $1 \mathrm{ml}$ recording chamber for submerged slices and continuously superfused, at a flow rate of $3 \mathrm{ml} / \mathrm{min}$, with gassed $(95 \%$ $\mathrm{O}_{2}$ and $5 \% \mathrm{CO}_{2}$ ) Krebs solution, kept at $30^{\circ} \mathrm{C}$, of the following composition: $\mathrm{NaCl} 125 \mathrm{mM}, \mathrm{KCl} 3 \mathrm{mM}, \mathrm{NaH}_{2} \mathrm{PO}_{4}$ $1.25 \mathrm{mM}, \mathrm{NaHCO}_{3} 25 \mathrm{mM}, \mathrm{CaCl}_{2} 2 \mathrm{mM}, \mathrm{MgSO}_{4} 1 \mathrm{mM}$ and glucose $10 \mathrm{mM}$. Drugs were added to this superfusion solution. Electrophysiological recordings of field excitatory postsynaptic potentials (fEPSP) were obtained as previously described (Cunha et al., 2000b). Stimulation (rectangular pulses of $0.1 \mathrm{~ms}$ applied once every $15 \mathrm{~s}$ ) was delivered through a bipolar concentric electrode placed on the Schaffer fibres, in the stratum radiatum near the CA3/CA1 border. Orthodromically evoked fEPSPs were recorded through an extracellular microelectrode $(4 \mathrm{M} \mathrm{NaCl}, 2-5 \mathrm{M} \Omega$ resistance) placed in the stratum radiatum of the CA1 area. The intensity of the stimulus was adjusted to evoke a fEPSP with an amplitude of $0.7-1 \mathrm{mV}$ without appreciable population spike contamination. Recordings were obtained with an Axoclamp 2B amplifier coupled to a DigiData 1200 interface (Axon Instruments) and averages of eight consecutive responses were continuously monitored on a personal computer with the LTP 1.01 software (Anderson and Collingridge, 1997). Responses were quantified as the initial slope of the averaged fEPSPs. The amplitude of the afferent presynaptic volley was quantified as a peak-to-peak measurement between the negative peak of the presynaptic volley and the positivity that immediately preceded this negative peak (Dunwiddie and Miller, 1993). To elicit paired-pulse facilitation (PPF), the Schaffer pathway was stimulated twice with $50 \mathrm{~ms}$ inter-pulse interval and the synaptic facilitation was quantified as the ratio $\left(\mathrm{P}_{2} / \mathrm{P}_{1}\right)$ between the slopes of the fEPSP elicited by the second $\left(\mathrm{P}_{2}\right)$ and the first $\left(\mathrm{P}_{1}\right)$ stimuli.

\section{3. $\left[{ }^{3} H\right]$ Glutamate release from hippocampal nerve terminals}

A synaptosomal fraction from the CA1 area of the rat hippocampus was prepared as previously described (Lopes et al., 2002) from male Wistar rats (6-8 weeks old; $150-210 \mathrm{~g}$ ) and resuspended in $1 \mathrm{ml}$ of gassed Krebs solution. The evoked release of $\left[{ }^{3} \mathrm{H}\right]$ glutamate was as previously described (Lopes et al., 2002). Basically, the synaptosomes were diluted 1:1 in gassed Krebs solution, equilibrated for $10 \mathrm{~min}$ at $37^{\circ} \mathrm{C}$, and labeled with $\left[{ }^{3} \mathrm{H}\right]$ glutamate $(0.2 \mu \mathrm{M})$ during $5 \mathrm{~min}$ at $37^{\circ} \mathrm{C}$ under direct but gentle bubbling with $95 \% \mathrm{O}_{2}$ and $5 \% \mathrm{CO}_{2}$. The synaptosomal suspension was then diluted 1:6 with gassed Krebs solution and layered over Whatman GF/C filters into four parallel $90 \mu \mathrm{l}$ superfusion chamber (adapted from Swinny filter holders, Millipore) through the aid of a roller pump (flow rate: $0.8 \mathrm{ml} / \mathrm{min}$, which was kept constant through the experiment). A series of four parallel superfusion chambers was used to enable both control and test conditions to be performed in duplicate from the same batch of synaptosomes. After setting up the synaptosomes, a 20 min equilibration period was performed before starting sample collection. The effluent was then collected in $1 \mathrm{~min}$ fractions for scintillation counting ( $500 \mu \mathrm{l}$ to $5 \mathrm{ml}$ Scintran Cocktail T, Wallac). Synaptosomal disruption during the experiments was small since only $3 \pm 2 \%$ of the total lactate dehydrogenase 
(EC 1.1.1.27) was released (see Cunha and Ribeiro, 1999).

The synaptosomes were stimulated with $20 \mathrm{mM} \mathrm{KCl}$ (isomolar substitution of $\mathrm{Na}^{+}$by $\mathrm{K}^{+}$in the Krebs superfusion solution) at 3 and 9 min after starting sample collection $\left(\mathrm{S}_{1}\right.$ and $S_{2}$ ). At the end of the experiments, the filters were removed from the superfusion chambers and analyzed by scintillation counting for determination of tritium retained by the synaptosomes. The amount of radioactivity released by each pulse $\left(S_{1}\right.$ and $\left.S_{2}\right)$ of potassium (evoked release) was calculated by integration of the area of the peak upon subtraction of the estimated basal tritium outflow from the total outflow of tritium obtained upon $\mathrm{K}^{+}$stimulation. The basal outflow was assumed to decline linearly from the 2 min interval before onset of stimulation to the fifth minute after onset of stimulation. The amount of radioactivity recovered in the effluent of the evoked release peak was mostly glutamate, as assessed by HPLC, and was essentially $\mathrm{Ca}^{2+}$-dependent (see Lopes et al., 2002). Thus, we considered that the evoked release of tritium in the present experimental conditions corresponds to a $\mathrm{Ca}^{2+}$-dependent $\left[{ }^{3} \mathrm{H}\right]$ glutamate release.

When the effect of domoate on the release of glutamate was investigated, domoate was added to the superfusion medium 2 min before $S_{2}$ and remained in the bath up to the end of the sample collection period. The effect of domoate was calculated as the percentage variation of the amount of tritium released in $S_{2}$ /amount of tritium released in $S_{1}$ in the presence of domoate versus the $S_{2} / S_{1}$ ratio in control conditions, in the same experiment using the same batch of synaptosomes. When we evaluated the changes of the effect of domoate by a modifier, this modifier was applied $15 \mathrm{~min}$ before the beginning of sample collection period and was present during $S_{1}$ and $S_{2}$. When present during $S_{1}$ and $S_{2}$, arachidonic acid $(10 \mu \mathrm{M})$, CNQX $(10 \mu \mathrm{M})$ or GYKI 52466 $(100 \mu \mathrm{M})$ did not significantly $(P>0.05)$ alter the $\mathrm{S}_{2} / \mathrm{S}_{1}$ ratio as compared with the $S_{2} / S_{1}$ ratio obtained in control conditions (no added drug).

\subsection{Binding assays}

Binding of $\left[{ }^{3} \mathrm{H}\right]-(2 S, 4 R)-4-m e t h y l g l u t a m a t e\left(\left[{ }^{3} \mathrm{H}\right] \mathrm{MGA}\right)$ was for $90 \mathrm{~min}$ at $4{ }^{\circ} \mathrm{C}$ with $116-235 \mu \mathrm{g}$ of synaptosomal membrane protein in a final volume of $300 \mu \mathrm{l}$ in the incubation buffer, essentially as previously described (Cunha et al., 1999). Specific binding was determined by subtraction of the non-specific binding, which was measured in the presence of $100 \mu \mathrm{M}$ kainate. The binding reactions were stopped by vacuum filtration through Whatman GF/C glass fiber filters, followed by washing of the filters and reaction tubes with $8 \mathrm{ml}$ of incubation buffer, kept at $4{ }^{\circ} \mathrm{C}$. The filters were then placed in scintillation vials with $5 \mathrm{ml}$ of scintillation liquid (Scintran T). Radioactivity bound to the filters was determined after $12 \mathrm{~h}$ with an efficiency of $55-60 \%$ for 2 min. Saturation curves were performed in triplicate with 10 different $\left[{ }^{3} \mathrm{H}\right] \mathrm{MGA}$ concentrations ranging from 0.3 to $120 \mathrm{nM}$. The amount of membrane protein was determined by the Lowry method (Cunha et al., 1999). The data were initially processed in Microsoft Excel software to determine the average specific binding, then fitted by non-linear regression using the Raphson-Newton method, performed with the GraphPAD InPlot Software package. An $F$-test $(P>0.05)$ was used to determine whether the curves were fitted best by one or two independent binding sites.

\subsection{Statistics}

The values presented are mean \pm S.E.M. of $n$ experiments, except $K_{\mathrm{D}}$ values which are presented as mean $(95 \%$ confidence interval). To test the significance of the effect of a drug versus control, a paired Student's $t$-test was used. When making comparisons from different set of experiments with control, a one-way variance analysis (ANOVA) was used, followed by a Dunnett's test. $P \leq 0.05$ was considered to represent a significant difference.

\section{Results}

\subsection{Synaptic transmission in CAl area of hippocampal slices}

The superfusion of rat hippocampal slices with increasing concentrations of domoic acid (60-300 nM) caused a concentration-dependent inhibition of synaptic transmission in Schaffer fiber/CA1 pyramid synapses, as measured by the decrease in the initial slope of the field excitatory postsynaptic potentials recorded in the stratum radiatum of CA1 area (Fig. 1). Kainate (0.3-3 $\mu \mathrm{M})$ also inhibited the fEPSP slope (data not shown). The depression of fEPSP caused by domoate or kainate fully recovered upon washout of the drugs and three series of cumulative application of three concentrations of domoate $(60,100$ and $300 \mathrm{nM})$ produced essentially similar depressions of fEPSP slope $(n=4)$. In parallel with the inhibition of fEPSP slope, domoate (60-100 nM) and kainate $(0.3-1 \mu \mathrm{M})$ induced a response with an epileptiform pattern (see Fig. 1B), which also disappeared upon washout of the drugs. This domoate-induced epileptogenic-like pattern was attenuated but did not disappear by cutting the connection between CA3/CA2 areas to CA1 area. The amplitude of the inhibition of fEPSP slope by domoate $(60-100 \mathrm{nM})$ and kainate $(0.3-1 \mu \mathrm{M})$ was similar irrespective of cutting CA3/CA1 connections. The kainate GluR6 receptor antagonist, NS-102 $(10 \mu \mathrm{M})$, which by itself was devoid of effects on fEPSP slope $(n=4)$, attenuated $(47-66 \%, n=2$ for each agonist) the inhibitory effect of both domoate $(60-300 \mathrm{nM})$ and of kainate $(0.6-3 \mu \mathrm{M})$ on fEPSP slope. Thus, as previously concluded by others (Chittajallu et al., 1996; Kamiya and Ozawa, 1998; Vignes et al., 1998; Frerking et al., 2001), the effect of domoate and kainate on excitatory synaptic transmission in hippocampal CA1 area is likely mediated by kainate receptors.

When arachidonic acid $(1-30 \mu \mathrm{M})$ was applied to rat hippocampal slices, it was essentially devoid of effects on 

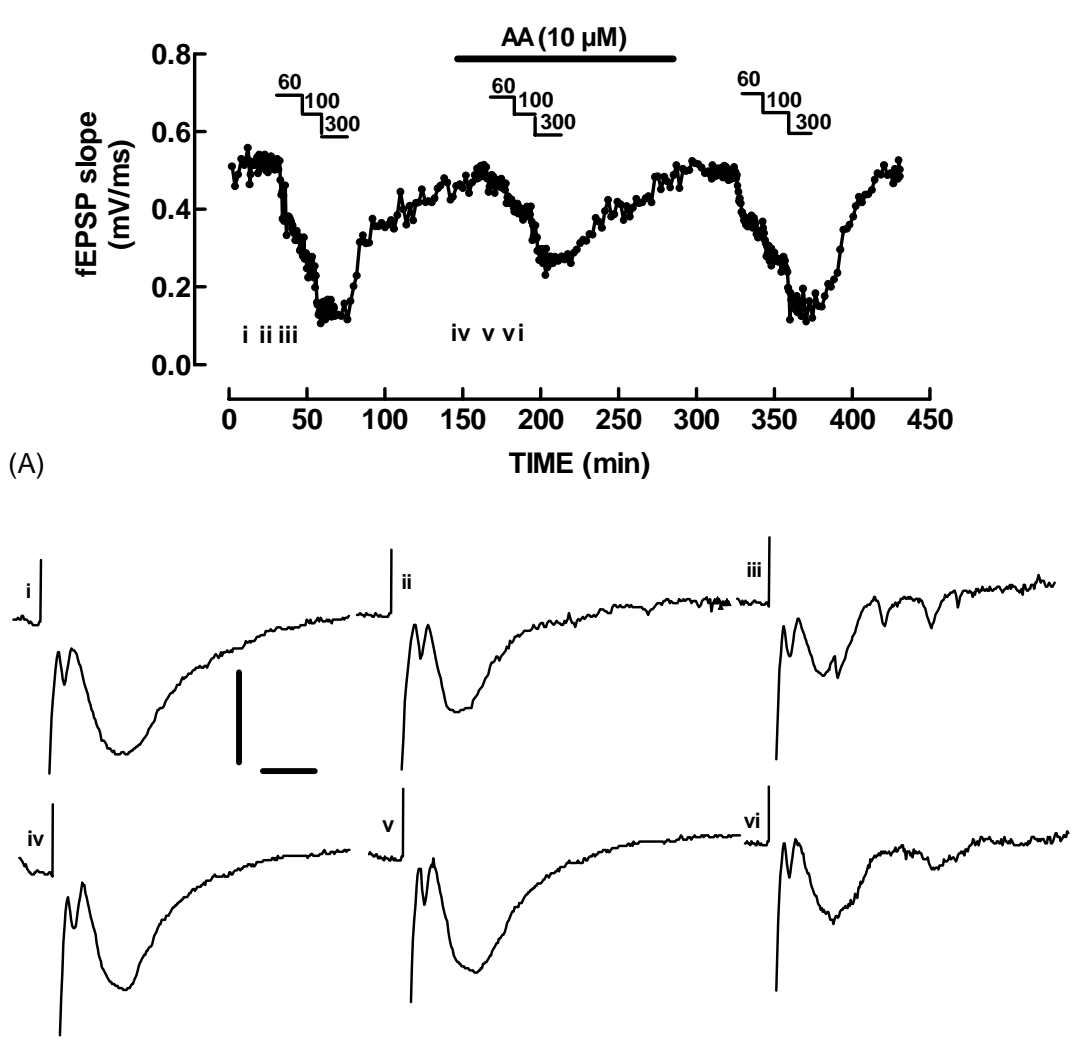

(B)

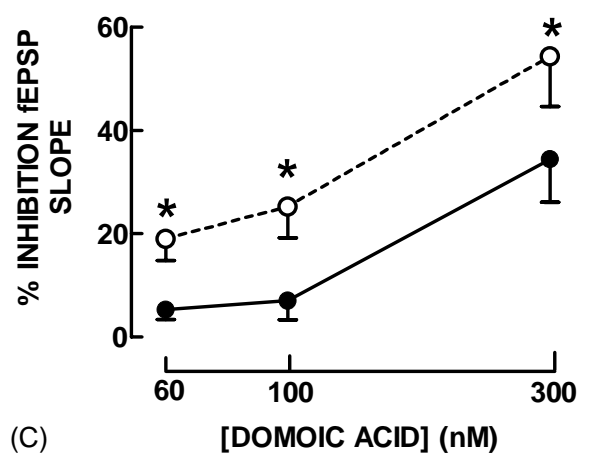

Fig. 1. Activation of kainate receptors inhibits synaptic transmission in Schaffer fibres/CA1 pyramid synapses of rat hippocampal slices and this effect is attenuated by arachidonic acid. Panel A shows an experiment monitoring the time course of field excitatory postsynaptic potential responses and the effect thereupon of the addition of three successive concentrations $(60,100$ and $300 \mathrm{nM})$ of the kainate receptor agonist, domoic acid first in the absence, then in the presence, then again in the absence of AA $(10 \mu \mathrm{M})$, as indicated in the upper bars. Each point corresponds to the averaged fEPSP slope of two consecutive fEPSP responses. Panel B shown averaged fEPSP responses at the time points indicated by the symbols ((i)-(vi)) shown above the abscissa in panel A, i.e. in control conditions (i); in the presence of $60 \mathrm{nM}$ (ii); and $100 \mathrm{nM}$ of domoic acid (iii). In the presence of AA (10 $\mu$ M) (iv); together with $60 \mathrm{nM}(\mathrm{v})$; and $100 \mathrm{nM}$ domoic acid (vi); a significant attenuation of the fEPSP slope induced by domoate was observed. The calibration bars correspond to $1 \mathrm{mV}$ and $5 \mathrm{~ms}$. Panel $\mathrm{C}$ represented the averaged percentage inhibition of fEPSP slope caused by domoic acid in the absence ( $\mathrm{O}$ ) and in the presence of $10 \mu \mathrm{M}$ AA $($ ). Zero percent corresponds to the fEPSP slope in control conditions (i.e. in the absence of any added drugs; $458 \pm 31 \mu \mathrm{V} / \mathrm{ms}$, a value not modified by $10 \mu \mathrm{M} \mathrm{AA}$ ) and $100 \%$ corresponds to the blockade of fEPSP response. Each value is the mean \pm S.E.M. of four experiments. ${ }^{*} P<0.05$ comparing the effect of each concentration of domoic acid in the absence and in the presence of AA (10 $\left.\mu \mathrm{M}\right)$.

fEPSP slope, as previously reported (Cunha et al., 2000b and references therein). However, in the presence of AA $(10 \mu \mathrm{M})$, the inhibitory effect of domoate $(60-300 \mathrm{nM})$ on fEPSP slope was significantly $(P<0.05)$ attenuated (Fig. 1). As illustrated in Fig. 1C, the inhibitory effect of AA was more intense at lower concentrations of domoate and tended to decrease with increasing concentrations of domoate (Fig. 1C). AA $(10 \mu \mathrm{M})$ also depressed the domoate-induced hyperexcitability in CA1 area as illustrated in Fig. 1 by the decreased appearance of secondary population spikes. AA attenuated in a concentration-dependent manner the domoate inhibition of fEPSP slope, with a maximal effect at $10 \mu \mathrm{M}$ AA (Fig. 2A). Thus, this concentration of AA was used to probe the effect of AA on hippocampal kainate receptors in most of the remaining experiments. 


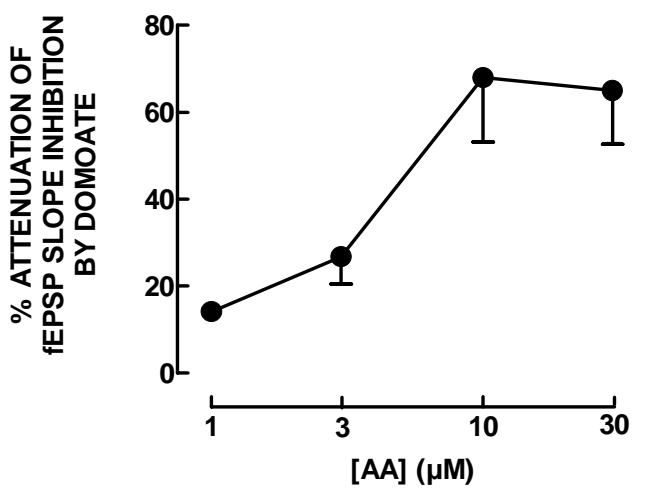

(A)

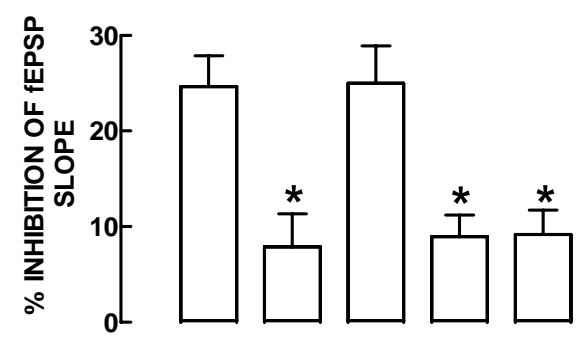

$\begin{array}{cccccc}\text { DOMOIC ACID }(100 \mathrm{nM}) & + & + & + & + & + \\ \text { AA }(10 \mu M) & - & + & + & + & + \\ \text { BSA }(1 \%) & - & - & + & - & - \\ \text { N-acetyl-L-cysteine }(0.5 \mathrm{mM})- & - & - & + & - \\ \text { NDGA }(50 \mu M)+\text { Indo }(20 \mu M) & - & - & - & - & +\end{array}$

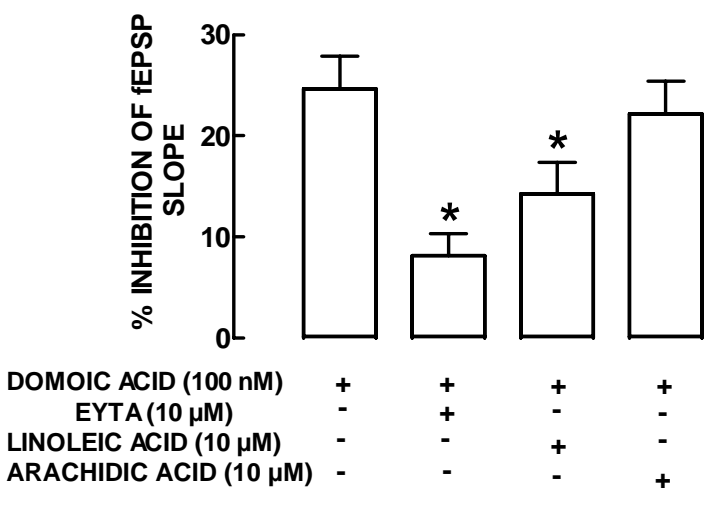

(C)

Fig. 2. Arachidonic acid attenuates the domoic acid-induced inhibition of field excitatory postsynaptic potential responses in a concentration-dependent manner and this AA effect is not due to lipoxygenase or cyclooxygenase metabolites and is mimicked by other cis-unsaturated, but not saturated, free fatty acids. Panel A shows the percentage attenuation by different concentrations of AA $(1-30 \mu \mathrm{M})$ of the inhibitory effect of domoic acid $(100 \mathrm{nM})$ on fEPSP slope. Zero percent corresponds to the inhibition of fEPSP slope caused by $100 \mathrm{nM}$ domoic acid (24 $\pm 4 \%$ nhibition) and $100 \%$ corresponds to blockade of the inhibitory effect of domoic acid, i.e. to the fEPSP slope value in control conditions in the absence of any drug $(529 \pm 36 \mu \mathrm{V} / \mathrm{ms})$. Each point corresponds to the mean \pm S.E.M. of three to four experiments. Panels B and C are also shown the percentage attenuation of fEPSP slope caused by $100 \mathrm{nM}$ domoic acid alone (first bar from the left in panels B and C), together with $10 \mu \mathrm{M} \mathrm{AA}$, together with bovine serum albumin (1\%, that quenches free fatty acids), with the free radical scavenger, $N$-acetyl-L-cysteine $(0.5 \mathrm{mM})$ with the simultaneous presence of the lypoxygenase inhibitor, nordihydroguaiaretic acid $(50 \mu \mathrm{M})$ and the cyclooxygenase inhibitor, indomethacin (Indo, $20 \mu \mathrm{M}$ ), and of $100 \mathrm{nM}$ domoic acid with the non-hydrolysable AA analogue, EYTA $(10 \mu \mathrm{M})$ or with the cis-unsaturated free fatty acid, linoleic
The effect of AA $(10 \mu \mathrm{M})$ on domoate $(100 \mathrm{nM})$-induced inhibition of fEPSP slope was prevented by bovine serum albumin $(1 \%, n=3)$, which binds free fatty acids (Fig. 2B), and was unaffected by the oxygen radical scavenger, $N$-acetyl-L-cysteine $(0.5 \mathrm{mM}, n=3)$ (Fig. 2B). Neither BSA $(1 \%, n=3)$ nor $N$-acetyl-L-cysteine $(0.5 \mathrm{mM}$, $n=3$ ) affected fEPSP slope. The simultaneous presence of the lipoxygenase inhibitor, nordihydroguaiaretic acid $(50 \mu \mathrm{M})$, and of the cyclooxygenase inhibitor, indomethacin $(20 \mu \mathrm{M})$, also failed to modify the effect of AA $(10 \mu \mathrm{M})$ on domoate $(100 \mathrm{nM})$-induced inhibition of fEPSP slope $(n=3)$ (Fig. 2B). The lack of involvement of AA metabolites was further strengthen by the observation that ETYA $(10 \mu \mathrm{M})$, an analogue of AA that mimics the effect of AA but cannot be metabolized, also depressed domoate $(100 \mathrm{nM})$-induced inhibition of fEPSP slope $(n=3)$, as did another cis-unsaturated fatty acid, linoleic acid $(10 \mu \mathrm{M}$, $n=3$ ) (Fig. 2C). In contrast, a $\mathrm{C}_{20}$ saturated free fatty acid, arachidic acid $(10 \mu \mathrm{M}, n=2)$, failed to affect the domoate $(100 \mathrm{nM})$-induced inhibition of fEPSP slope (Fig. 2C).

\subsection{Paired-pulse facilitation in CAl area of hippocampal slices}

When two consecutive pulses are applied to the afferent Schaffer fibers with an interval of $50 \mathrm{~ms}$, the fEPSP response to the second pulse showed a larger slope (Fig. 3) as a result of presynaptic calcium accumulation (Wu and Saggau, 1994). This paired-pulse facilitation is enhanced by drugs presynaptically inhibiting glutamate release and is inhibited by drugs presynaptically facilitating glutamate release, provided these modulatory systems control calcium transients (Wu and Saggau, 1994). Consistent with a presynaptic effect of kainate receptors to modulate fEPSP in CA1 area (Chittajallu et al., 1996; Kamiya and Ozawa, 1998; Vignes et al., 1998; Frerking et al., 2001), domoate $(60-300 \mathrm{nM})$ increased the ratio of PPF in a concentration-dependent manner (Fig. 3). Like the inhibitory effect of domoate on fEPSP slope, the PPF ratio rapidly recovered to control value upon washout of domoate (data not shown).

By itself, AA $(10 \mu \mathrm{M})$ slightly inhibited PPF $(8 \pm 2 \%$, $n=4$ ), probably as a consequence of the ability of AA to modulate calcium transients in hippocampal nerve terminals (Damron and Dorman, 1993). As illustrated in Fig. 3, AA $(10 \mu \mathrm{M})$ attenuated the facilitatory effect of domoate $(60-300 \mathrm{nM})$ on PPF.

acid $(10 \mu \mathrm{M})$ or with the saturated free fatty acid, arachidic acid $(10 \mu \mathrm{M})$. Each bar is the mean \pm S.E.M. of three experiments, except the bar corresponding to the lack of effect of arachidic acid on $100 \mathrm{nM}$ domoic acid inhibition on fEPSP slope in panel $\mathrm{C}$, which is mean \pm S.D. of two experiments. ${ }^{*} P<0.05$ compared to the effect of $100 \mathrm{nM}$ domoic acid alone (first bar from the left in panels B and C). 

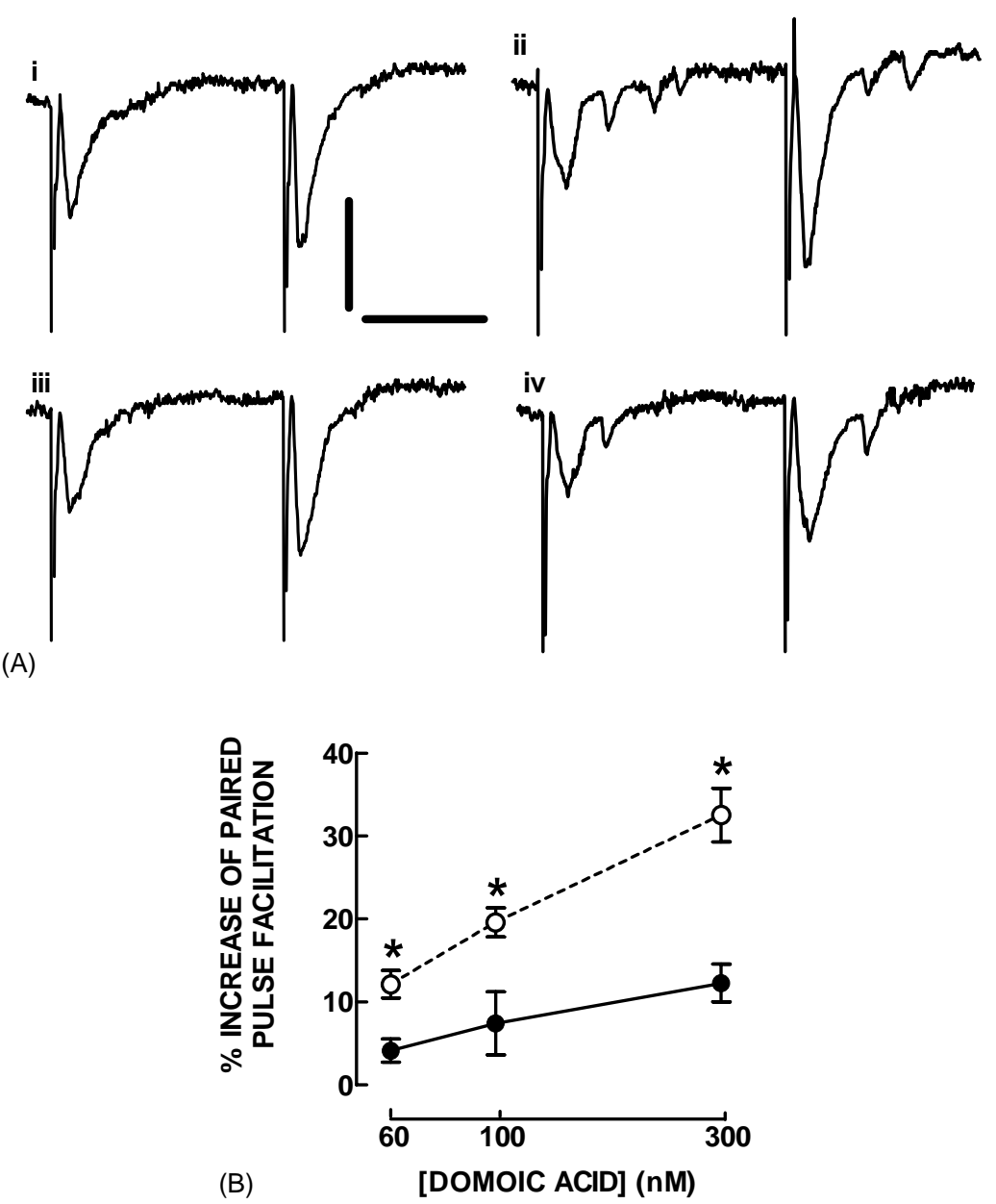

Fig. 3. Activation of kainate receptors increases paired-pulse facilitation in rat hippocampal slices and this effect is attenuated by arachidonic acid. Panel A shows recordings with twin field excitatory postsynaptic potential responses recorded extracellularly in Schaffer fibres/CA1 pyramid synapses upon two consecutive stimulation pulses separated by $50 \mathrm{~ms}$. In the first trace corresponding to control conditions (i), the second fEPSP response is larger than the first (PPF); and $100 \mathrm{nM}$ domoic acid (ii) facilitates PPF. In the second row of recordings is first shown the PPF in the presence of $10 \mu \mathrm{M}$ AA (iii); and then in the simultaneous presence of $10 \mu \mathrm{M}$ AA and $100 \mathrm{nM}$ domoic acid (iv). The calibration bars correspond to $1 \mathrm{mV}$ and $25 \mathrm{~ms}$. Note that in this series of recordings, the connection between CA3 and CA1 area was cut and the domoate-induced epileptogenesis (illustrated in the recording in Fig. 1) is drastically reduced. Panel B represented the average percentage facilitation of PPF caused by domoic acid in the absence ( $\bigcirc$ ) and in the presence of $10 \mu \mathrm{M}$ AA ( ). Zero percent corresponds to the PPF in control conditions $(1.88 \pm 0.05$ in the absence of any drugs or $1.73 \pm 0.05$ in the presence of $10 \mu \mathrm{M} \mathrm{AA})$ and $100 \%$ corresponds to the double of these values. Each value is the mean \pm S.E.M. of four experiments. ${ }^{*} P<0.05$ comparing the effect of each concentration of domoic acid in the absence and in the presence of $10 \mu \mathrm{M}$ AA.

\subsection{Glutamate release from hippocampal synaptosomes}

When CA1 hippocampal synaptosomes, previously loaded with $\left[{ }^{3} \mathrm{H}\right]$ glutamate, were stimulated for $30 \mathrm{~s}$ with $20 \mathrm{mM} \mathrm{K}^{+}$, they released tritium in a $\mathrm{Ca}^{2+}$-dependent manner that is mostly $\left[{ }^{3} \mathrm{H}\right]$ glutamate, as assessed by HPLC (see Lopes et al., 2002). Two periods of chemical stimulation $\left(S_{1}\right.$ and $\left.S_{2}\right)$, separated by a 6 min interval, produced a similar evoked tritium release (Fig. $4 \mathrm{~A}$ ), with an $\mathrm{S}_{2} / \mathrm{S}_{1}$ ratio of $0.89 \pm 0.02(n=15)$. As illustrated in Fig. 4A, domoate $(3 \mu \mathrm{M})$ enhanced by $14 \pm 4 \%(n=4)$ the basal outflow of tritium, in accordance with the ability of kainate receptors to trigger calcium influx and the spontaneous release of glutamate from hippocampal nerve terminals (reviewed in Malva et al., 1998). Consistent with its effect on glutamatergic transmission, application of $3 \mu \mathrm{M}$ domoate $2 \mathrm{~min}$ before the second stimulation period $\left(\mathrm{S}_{2}\right)$ caused a decreased $\mathrm{K}^{+}$-evoked release of tritium (Fig. 4A). As illustrated in Fig. 4B, this inhibitory effect of domoate on the evoked release of glutamate was attenuated by $88 \pm 11 \%(n=4)$ by the ionotropic non-NMDA receptor antagonist, CNQX $(10 \mu \mathrm{M})$, but not by the non-competitive AMPA receptor antagonist, GYKI $52466(100 \mu \mathrm{M}, n=3)$. Also, as illustrated in Fig. 4C, this inhibitory effect of domoate $(1-10 \mu \mathrm{M})$ on the evoked release of glutamate was concentration-dependent. As observed when studying glutamatergic transmission, AA $(10 \mu \mathrm{M})$ decreased the domoate $(1-10 \mu \mathrm{M})$-induced inhibition of evoked glutamate release (Fig. 4C). 


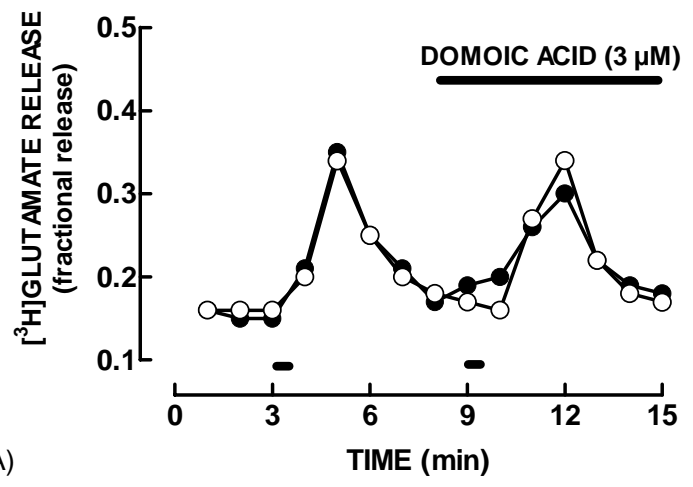

(A)
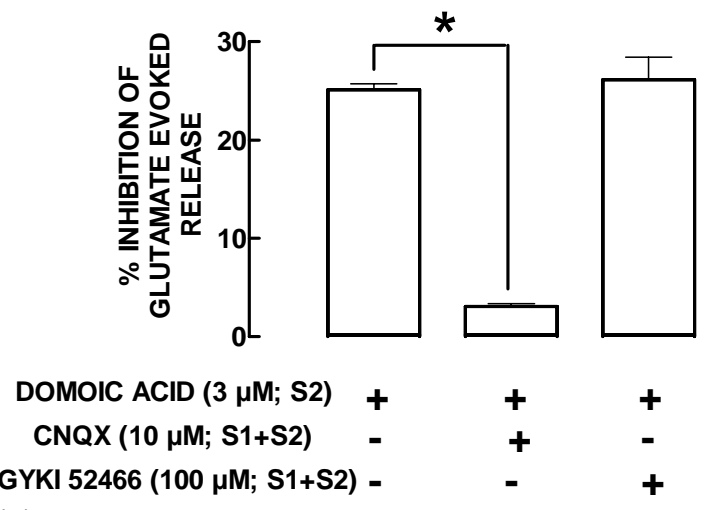

(B)

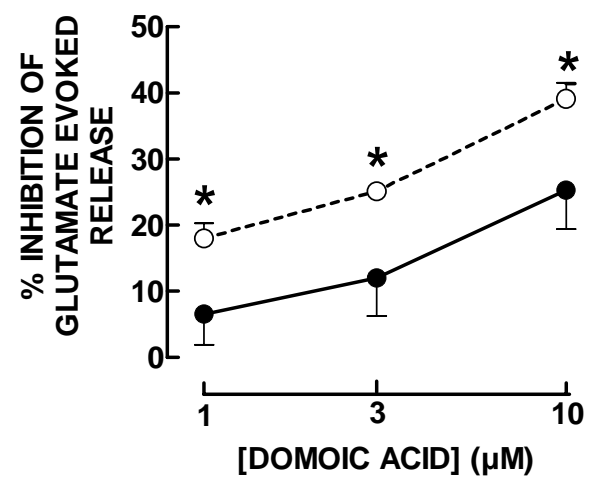

Fig. 4. Activation of presynaptic kainate receptors inhibits the evoked release of glutamate from rat hippocampal synaptosomes and this effect is attenuated by arachidonic acid. Panel A shown the time course of $\left[{ }^{3} \mathrm{H}\right]$ glutamate release, measured as the fractional release expressed in terms of percentage of total radioactivity present in the synaptosomes at the beginning of the collection of each sample. The synaptosomes were challenged with two periods of stimulation with $20 \mathrm{mM} \mathrm{K}^{+}$for $30 \mathrm{~s}$ ( $\mathrm{S} 1$ and $\mathrm{S} 2$ ), as indicated by the bars above the abcissa. The symbols (O) represent tritium release from a control chamber, to which no drug was added, and the symbols (-) represent the tritium release in the test chamber, to which domoic acid $(3 \mu \mathrm{M})$ was added through the superfusate, as indicated by the upper bar. Note that domoic acid $(3 \mu \mathrm{M})$ enhanced the basal outflow of glutamate and inhibited the evoked release of glutamate. Panel B shows the ability of the ionotropic non-NMDA receptor antagonist, CNQX $(10 \mu \mathrm{M})$, but not the AMPA receptor antagonist, GIKY $52466(100 \mu \mathrm{M})$, to prevent the effect of domoic acid on the evoked release of glutamate. The drugs were present in S1 and/or S2 as indicated under the bars. The results are mean \pm S.E.M. of three to four experiments. ${ }^{*} P<0.05$ vs. the inhibitory effect of domoic acid (first left column). Panel $\mathrm{C}$ shows the concentration-dependent inhibitory effect of domoic acid on the evoked release of glutamate in the absence $(O)$ and
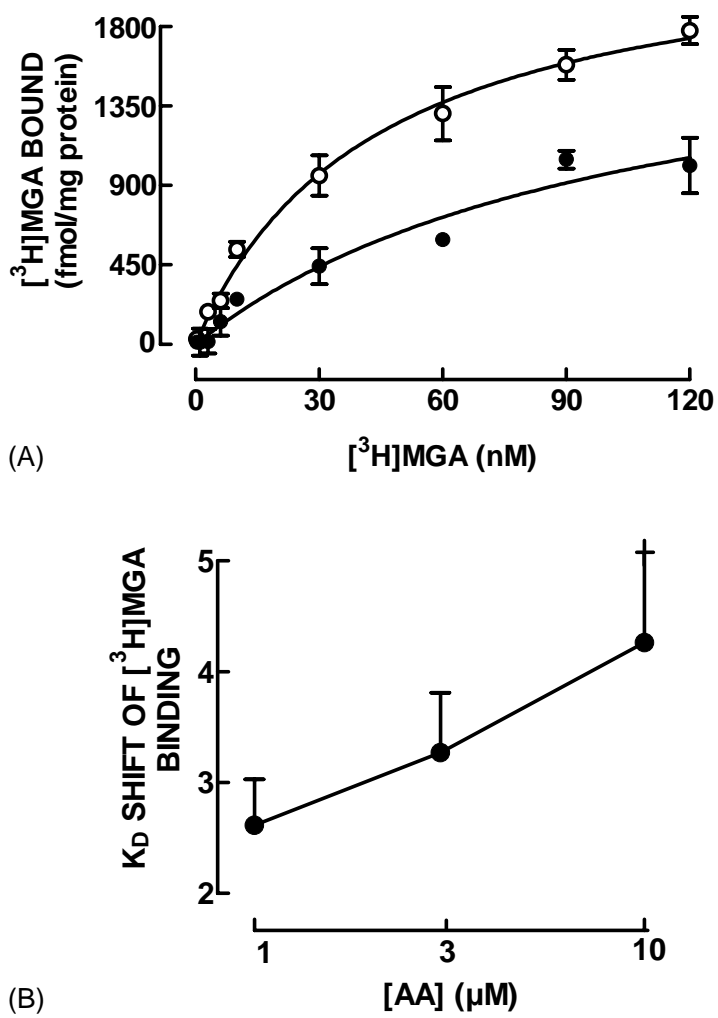

(B)

[AA] $(\mu \mathrm{M})$

Fig. 5. Inhibition by arachidonic acid of the binding of the selective kainate receptor agonist, $\left[{ }^{3} \mathrm{H}\right]-(2 S, 4 R)-4$-methylglutamate, to synaptosomal membranes of the rat hippocampus. Panel A shows the average saturation curves of $\left[{ }^{3} \mathrm{H}\right] \mathrm{MGA}$ binding in the absence $(O)$ or presence $(-)$ of AA $(10 \mu \mathrm{M})$. The ordinates represent specific binding of $\left[{ }^{3} \mathrm{H}\right] \mathrm{MGA}$ upon subtraction of the non-specific binding, determined in the presence of $100 \mu \mathrm{M}$ kainate, from total binding. The curves were generated from the average binding parameters obtained upon fitting by non-linear regression assuming a single binding site. Results are mean \pm S.E.M. of three to nine experiments performed in triplicate. Panel B shows the concentration-dependent inhibition by AA of the affinity of $\left[{ }^{3} \mathrm{H}\right] \mathrm{MGA}$ binding, measured as the ratio of the $K_{\mathrm{D}}$ values of $\left[{ }^{3} \mathrm{H}\right] \mathrm{MGA}$ in the absence/presence of AA ( $K_{\mathrm{D}}$ shift), estimated from saturation curves similar to these presented in panel A. Each point is the mean \pm S.E.M. of three to four experiments.

\subsection{Binding to hippocampal synaptosomal membranes}

In control conditions, the binding of the kainate receptor agonist, $\left[{ }^{3} \mathrm{H}\right]-(2 S, 4 R)-4$-methylglutamate, to hippocampal synaptosomal membranes displayed a $K_{\mathrm{D}}$ of $48 \mathrm{nM}$ (95\% confidence interval: $40-55 \mathrm{nM}$ ) and a $B_{\max }$ of $1910 \pm 71 \mathrm{fmol} / \mathrm{mg}$ protein $(n=9)$. As illustrated in Fig. 5A, the presence of AA $(10 \mu \mathrm{M}, n=3)$ in the binding assay

in the presence of $10 \mu \mathrm{M}$ AA (-). Zero percent corresponds to the S2/S1 ratio in control conditions $(0.96 \pm 0.04$, not modified by $10 \mu \mathrm{M}$ AA) and $100 \%$ corresponds to the full blockade of the evoked release of tritium $(\mathrm{S} 2 / \mathrm{S} 1=0)$. The results are mean \pm S.E.M of three to four experiments. ${ }^{*} P<0.05$ comparing the effect of each concentration of domoic acid in the absence and in the presence of $10 \mu \mathrm{M}$ AA. 
shifted the saturation isotherm of $\left[{ }^{3} \mathrm{H}\right] \mathrm{MGA}$ binding to the right, with a $224 \pm 36 \%$ increase in $K_{\mathrm{D}}$ value $(87-125 \mathrm{nM})$ and no significant change in $B_{\max }(1872 \pm 58 \mathrm{fmol} / \mathrm{mg}$ protein). This inhibition by AA of $\left[{ }^{3} \mathrm{H}\right] \mathrm{MGA}$ binding was concentration-dependent, increasing from 1 to $10 \mu \mathrm{M}$ (Fig. 5B).

\section{Discussion}

The main finding of the present work is that AA directly attenuates the inhibitory effect of presynaptic kainate receptors in glutamatergic nerve terminals of the rat hippocampus. Thus, AA attenuated the kainate receptor-induced inhibition of fEPSP slope and facilitation of paired-pulse facilitation in Schaffer fibre/CA1 pyramid synapses. Furthermore, AA also attenuated the kainate receptor-induced inhibition of the evoked release of glutamate from hippocampal nerve terminals. This effect of AA on presynaptic kainate receptors is likely to be a direct effect of AA, rather than involving intracellular transducing systems, since AA directly attenuated the binding to kainate receptors in purified membranes from hippocampal nerve terminals.

Kainate receptors inhibiting glutamatergic transmission in area CA1 of the hippocampus have previously been described (Chittajallu et al., 1996; Kamiya and Ozawa, 1998; Vignes et al., 1998; Frerking et al., 2001). These kainate receptors inhibiting glutamatergic transmission are presynaptic, as previously proposed (reviewed in Kamiya, 2002), since both kainate and domoate increased paired-pulse facilitation (see also Kamiya and Ozawa, 1998) and directly inhibited the evoked release of glutamate from purified nerve terminals in a manner sensitive to the ionotropic non-NMDA receptor antagonist, CNQX, but not to the selective AMPA receptor antagonist, GYKI 52466 (see also Chittajallu et al., 1996). This pharmacological profile indicates the involvement of kainate receptors, which are enriched in membranes from presynaptic nerve terminals in the hippocampus (Cunha et al., 1999).

We now observed that AA inhibits presynaptic kainate receptors, in a manner similar to the previously reported inhibition by AA of the cationic current triggered by postsynaptic kainate receptors in the hippocampus or by heterologously expressed kainate receptors (Wilding et al., 1998). Thus, it appears that AA may interfere with the activation of kainate receptors by agonists, irrespective of whether kainate receptors will trigger a cationic current or a metabotropic action, as is the case of presynaptic kainate receptors in the CA1 area (Rodríguez-Moreno and Lerma, 1998; Cunha et al., 2000a,b; Frerking et al., 2001). This effect of AA is likely to be a direct effect not involving lipoxygenase or cyclooxygenase metabolites, since the effect of AA was unaffected by cyclooxigenase or lipoxygenase inhibitors and was mimicked by the non-hydrolyzable but equi-effective analogue of AA, EYTA. The possible involvement of free radicals was also directly excluded by the observation that a free radical scavenger, $N$-acetyl-L-cysteine, failed to modify the effect of AA on kainate receptor-mediated actions. AA also directly inhibited the binding to kainate receptors in presynaptic hippocampal membranes, a preparation where transducing systems are disrupted since there is no intact cytoplasm, excluding any possible indirect effect of AA on transducing system controlling kainate receptor function (reviewed in Lerma et al., 2001).

In conclusion, the present results further add to previous observations suggesting that pre- and postsynaptic kainate receptors display similar pharmacological properties in spite of the fact that they operate differently (i.e. metabotropic and inhibitory versus ionotropic and excitatory, respectively). Further attempts need to be essayed to find ways of pharmacologically interfering with pre- and postsynaptic kainate receptors to understand their relative impact on different physiological and pathological processes (see Lerma et al., 2001).

\section{Acknowledgements}

Supported by Fundação para a Ciência e Tecnologia (Praxis/2/2.1/SAU/1348/95 and POCTI/1999/36491/99).

\section{References}

Anderson, W.W., Collingridge, G.L., 1997. A data acquisition program for on-line analysis of long-term potentiation and long-term depression. Soc. Neurosci. Abst. 23, 665.

Chittajallu, R., Vignes, M., Dev, K.K., Barnes, J.M., Collingridge, G.L., Henley, J.M., 1996. Regulation of glutamate release by presynaptic kainate receptors in the hippocampus. Nature 379, 78-81.

Cunha, R.A., Ribeiro, J.A., 1999. Facilitation of GABA release by arachidonic acid in rat hippocampal synaptosomes. Eur. J. Neurosci. $11,2171-2174$

Cunha, R.A., Malva, J.O., Ribeiro, J.A., 1999. Kainate receptors coupled to Gi/Go proteins in the rat hippocampus. Mol. Pharmacol. 56, 429433.

Cunha, R.A., Malva, J.O., Ribeiro, J.A., 2000a. Pertussis toxin prevents presynaptic inhibition by kainate receptors of rat hippocampal $\left[{ }^{3}\right.$ H]GABA release. FEBS Lett. 469, 159-162.

Cunha,

R.A., Almeida, T., Ribeiro, J.A., 2000b. Modification by arachidonic acid of extracellular adenosine metabolism and neuromodulatory action in the rat hippocampus. J. Biol. Chem. 275, 37572-37581.

Damron, D.S., Dorman, R.V., 1993. Involvement of phospholipase $\mathrm{A}_{2}$ and arachidonic acid in the depolarization-evoked accumulation of $\mathrm{Ca}^{2+}$ in hippocampal mossy fiber nerve endings. Neurochem. Res. 18, 12311237.

Freeman, E.J., Terrian, D.M., Dorman, R.V., 1990. Presynaptic facilitation of glutamate release from isolated hippocampal mossy fiber nerve endings by arachidonic acid. Neurochem. Res. 15, 743-750.

Frerking, M., Scmitz, D., Zhou, Q., Johansen, J., Nicoll, R.A., 2001. Kainate receptors depress excitatory synaptic transmission at CA3 $\rightarrow$ CA1 synapses in the hippocampus via a direct presynaptic action. J. Neurosci. 21, 2956-2958.

Kamiya, H., 2002. Kainate receptor-dependent presynaptic modulation and plasticity. Neurosci. Res. 42, 1-6.

Kamiya, H., Ozawa, S., 1998. Kainate receptor-mediated inhibition of presynaptic $\mathrm{Ca}^{2+}$ influx and EPSP in area CA1 of the rat hippocampus. J. Physiol. (London) 509, 833-845. 
Kovalchuck, Y., Miller, B., Sarantis, M., Attwell, D., 1994. Arachidonic acid depresses non-NMDA receptor currents. Brain Res. 643, 287-295.

Lerma, J., Paternain, A.V., Rodríguez-Moreno, A., López-García, J., 2001. Molecular physiology of kainate receptors. Physiol. Rev. 81, 971-998.

Lopes, L.V., Cunha, R.A., Kull, B., Fredholm, B.B., Ribeiro, J.A., 2002. Adenosine $A_{2 A}$ receptor facilitation of hippocampal synaptic transmission is dependent on tonic $A_{1}$ receptor inhibition. Neuroscience 112, 319-329.

Lynch, M.A., Clements, M.P., Voss, K.L., Bramham, C.R., Bliss, T.V.P., 1991. Is arachidonic acid a retrograde messenger in long-term potentiation? Biochem. Soc. Trans. 19, 391-396.

Malva, J.O., Carvalho, A.P., Carvalho, C.M., 1998. Kainate receptors in hippocampal CA3 subregion: evidence for a role in regulating neurotransmitter release. Neurochem. Int. 32, 1-6.

Malva, J.O., Silva, A.P., Cunha, R.A., 2003. Presynaptic modulation controlling neuronal excitability and epileptogenesis: role of kainate, adenosine and neuropeptide $\mathrm{Y}$ receptors. Neurochem. Res. 28, 1499-1513.

Meves, H., 1994. Modulation of ion channels by arachidonic acid. Prog. Neurobiol. 43, 175-186.
Miller, B., Sarantis, M., Traynelis, S.F., Attwell, D., 1992. Potentiation of NMDA receptor current by arachidonic acid. Nature 355, 722-725.

Rodríguez-Moreno, A., Lerma, J., 1998. Kainate receptor modulation of GABA release involves a metabotropic function. Neuron 20, 12111218.

Rodríguez-Moreno, A., López-Garcia, J.C., Lerma, J., 2000. Two populations of kainate receptors with separate signaling mechanisms in hippocampal interneurons. Proc. Natl. Acad. Sci. U.S.A. 97, 12931298.

Vignes, M., Clarke, V.R.J., Parry, M.J., Bleakman, D., Lodge, D., Ornstein, P.L., Collingridge, G.L., 1998. The GluR5 subtype of kainate receptor regulates excitatory synaptic transmission in areas CA1 and CA3 of the rat hippocampus. Neuropharmacology 37, 1269-1277.

Wilding, T.J., Chai, T.H., Huettner, J.E., 1998. Inhibition of rat neuronal kainate receptors by cis-unsaturated fatty acids. J. Physiol. (London) 513, 331-339.

Wu, L.G., Saggau, P., 1994. Presynaptic calcium is increased during normal synaptic transmission and paired-pulse facilitation, but not in long-term potentiation in area CA1 of hippocampus. J. Neurosci. 14, 645-654. 